\title{
ГІутешествия, открытия
}

УДК 910.4

\section{Как на месте «белого пятна» В центре Памира были открыты крупнейший ледник и высочайшая вершина}

\author{
(C) 2014 г. В.М. Котляков \\ Институт географии РАН, Москва \\ vladkot6@gmail.com
}

\section{A story about the discovery of the largest glacier and the highest peak in heart of the Pamirs}

V.M. Kotlyakov

Institute of Geography, Russian Academy of Sciences, Moscow

Географическое открытие, ледники, Памир, Таджикско-Памирская экспедиция. Geographical discovery, glaciers, Pamir, Tajik-Pamir Expedition.

Статья принята к печати 6 февраля 2014 г.

Рассказывается об открытии в конце XIX в. крупнейшего на Памире ледника Федченко и о запутанной истории восстановления реальной орографии Центрального Памира. Главная заслуга в этом принадлежит Таджикско-Памирской экспедиции, работавшей на Памире в 1928-1932 гг. Высочайшая точка Памира (7495 м) была обнаружена при съёмке геодезистом И.Г. Дорофеевым, письмо которого к автору и обсуждается в этой статье.

The paper describes how at the end of 19th century the largest Fedchenko Glacier had been revealed in the Pamirs, and about an intricate history of recovery the real orography of the Central Pamirs. The credit for that was given to the Tadzhik-Pamir expedition which worked there in 1928-1932. This highest peak of the Pamirs (7495 m) had been found by geodesist I.G. Dorofeev during his surveying of the mountains. His letter to the author is discussed here.

В 1960-70-е годы в Советском Союзе впервые в мире создавался Каталог ледников нашей страны, и с этой целью во многих горных системах проводились специальные исследования. Институт географии АН СССР в 1968-1974 гг. организовал Памирскую аэрогляциологическую экспедицию, выполнявшую исследования на мало изученном тогда Центральном Памире. Полёты на вертолёте рядом с высочайшими пиками, походы по диким ущельям и коварным ледникам, неожиданные встречи в горах, наконец, необыкновенная прелесть дикой природы произвели на меня такое впечатление, что при первой же возможности я сел за стол и в течение месяца написал книгу «Горы, льды и гипотезы», которая в 1977 г. увидела свет и имела большой успех. Я получил десятки восторженных писем от знакомых и незнакомых людей с впечатлениями от книги, но самым дорогим для меня было письмо очевидца событий конца 1920-х годов, участника знаменитой Таджикско-Памирской экспедиции, по существу первооткрывателя высочайшей вершины Памира - пика Сталина/Коммунизма/Исмоила Сомони - Ивана Георгиевича Дорофеева. В письмо были вложены оригинальные схемы Центрального Памира, имеющие несомненную историческую ценность. В этой публикации я расскажу о событиях 1928-1932 гг., используя материалы своей книги ${ }^{1}$, двух книг И.Г. Дорофеева ${ }^{2}$ и присланное им письмо.

В 1878 г. В.Ф. Ошанин, исследовавший северный склон большой горной цепи, которой он дал название хребта Петра Первого, отправился вдоль этого хребта в поисках путей на Восточный Памир. Поднимаясь в середине сентября по долине р. Муксу, он пересёк реки Сауксай и Каинды и продолжал путешествие по правому берегу р. Сельдары в направлении на юг, куда уводила долина. Неожиданно Ошанин сделал важное открытие: «Поперек долины проходит какой-то вал, который нигде не представлял значительного понижения, и я недоумевал, каким образом река не размыла этого, по-видимому, ничтожного препятствия... Когда мы приблизились на какие-нибудь полверсты, дело разъяснилось. Перед нами был конец громадного ледника».

Много признаков говорило о громадных размерах ледника, но от конца языка он просматривался вверх по течению всего километров на пятнадцать. В соседнем кишлаке Алтын-Мазар

\footnotetext{
${ }^{1}$ Котляков В.М. Горы, льды и гипотезы. Л.: Гидрометеоиздат, 1977. 167 с. Переиздание: Котляков В.М. Избранные сочинения: Т. 4. Льды, любовь и гипотезы. М.: Наука, 2001. С. 197-352.

${ }^{2}$ Дорофеев И.Г. На заоблачных высотах. М.: Мысль, 1976. 221 с. Дорофеев И.Г. В сердце Памирских гор. М.: Мысль, 1980. 160 с.
} 


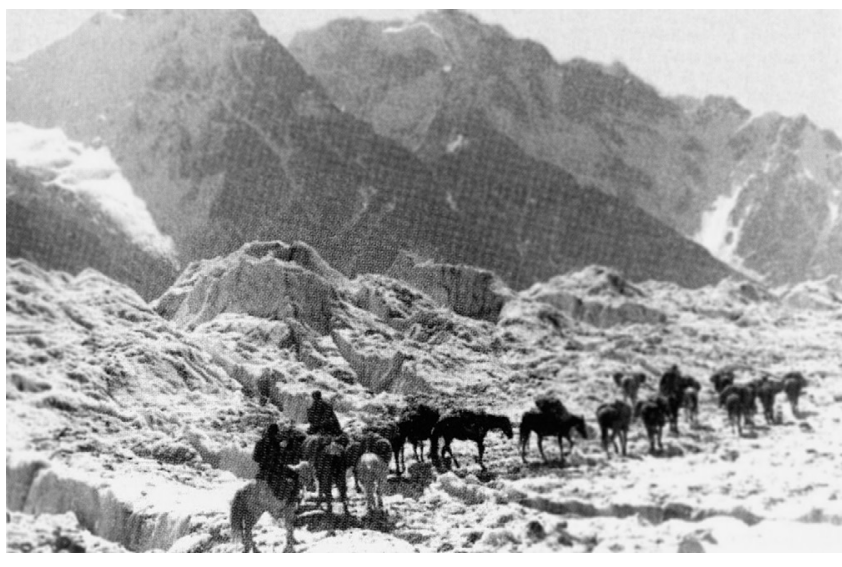

Рис. 1. Караван идёт по леднику к высокогорной станции Fig. 1. Caravan at the glacier surface on the way to a high mountain station

старик киргиз рассказал Ошанину, что длина ледника 30-40 вёрст и что он уходит к истокам Ванча, где есть трудно проходимый перевал. Отряд Ошанина не смог выйти на ледник - люди не были готовы к переходу по льду. В.Ф. Ошанин решил дать ему имя Федченко.

В 1884-1885 гг. несколько попыток достичь центра Памира сделал Г.Е. Грумм-Гржимайло. Он посетил Каратегин, Дарваз и хотел с запада проникнуть к леднику Федченко, но помешала плохая погода. Тем не менее, на основании виденного и услышанного на Памире он сделал важное предположение - впоследствии оправдавшееся - об орографическом строении этой части горной страны. 4 декабря 1885 г. на общем собрании Русского географического общества Грумм-Гржимайло сказал:

«В особенности любопытна северная часть этих нагорий, любопытна потому, что здесь мы должны предполагать громаднейшее поднятие, узел, от которого, как от центра, во все стороны разбегаются громадные кряжи неровной длины.

Этот узел у туземцев носит название Сель-тау, что значит «ледяная гора». С нее то к северу, то к югу и западу спускаются ледники, о грандиозных размерах которых мы можем судить только приблизительно. Северный из них назван В.Ф. Ошаниным ледником Федченко, по-видимому, самый длинный из них и находится в полной связи с другим ледником, идущим на запад и, по-видимому, замкнутым между упомянутой выше Сель-тау и горой Узтерги, что значит в переводе «болит голова», «кружит голова», название, которое прямо указывает на замечательную высоту этой горы. И действительно, туземцы уверяли меня, что выше этой горы нет в мире другой... влезть на нее невозможно».
В конце XIX и начале XX вв. на Памир часто снаряжались экспедиции, но лишь немногим путешественникам удалось пробраться в труднодоступные ущелья Центрального Памира. Для нас наиболее интересно вспомнить об экспедиции топографа Н.И. Косиненко. В июле 1909 г. его небольшой караван поднялся на ледник Федченко и, пройдя 7 км по неровному моренному покрову на льду, израненные и усталые лошади вышли на чистый лёд (рис. 1).

«Впереди раскрылась пустынная ледяная поверхность», - записал Н.И. Косиненко. Он увидел ледник на протяжении нескольких десятков километров. На 25-м километре дорогу преградили глубокие трещины, и отряд был вынужден свернуть на боковой приток, где через 7 км на зелёной лужайке рядом с ледником устроили большой бивак, давший имя левому притоку ледника Федченко - его назвали Бивачный.

В поисках легендарного перевала Кашалаяк Косиненко налегке вышел на основной ствол ледника Федченко и прошёл по нему ещё около 15 км, пока дорога не стала окончательно непроходимой. Впереди, всего в 15-20 км, на гребне хребта виднелась высокая заснеженная вершина. Потрать он ещё несколько дней на попытки дойти до цели - и, возможно, загадка орографии Памира разрешилась бы гораздо раньше.

Следующая страница этой истории связана с именем астронома Я.И. Беляева. В середине июля 1916 г. отряд, состоящий из двух исследователей и 12 носильщиков-таджиков, отправился вверх по леднику Гармо. Вскоре люди увидели большой ледник, впадавший в Гармо слева (ныне он называется ледником Шокальского). На северо-востоке виднелась вершина, которую Беляев принял за один из алтын-мазарских пиков. Ещё дальше к востоку просматривалась более высокая вершина, по мнению Беляева, находившаяся недалеко от перевала Кашалаяк.

Через несколько дней отряд подошёл к месту слияния трёх ледяных потоков, составляющих ледник Гармо. Беляев измерил длину ледника Гармо и поразился его размерам - более 27 км. В истоках ледника была видна мощная пирамидальная вершина. Беляев ошибочно посчитал, что это пик Гармо, хорошо известный местным жителям. Выполнив астрономические наблюдения, исследователь нанёс «пик Гармо» на карту (рис. 2). Эта ошибка Беляева придала всей дальнейшей истории открытия Центрального Памира детективный характер. 


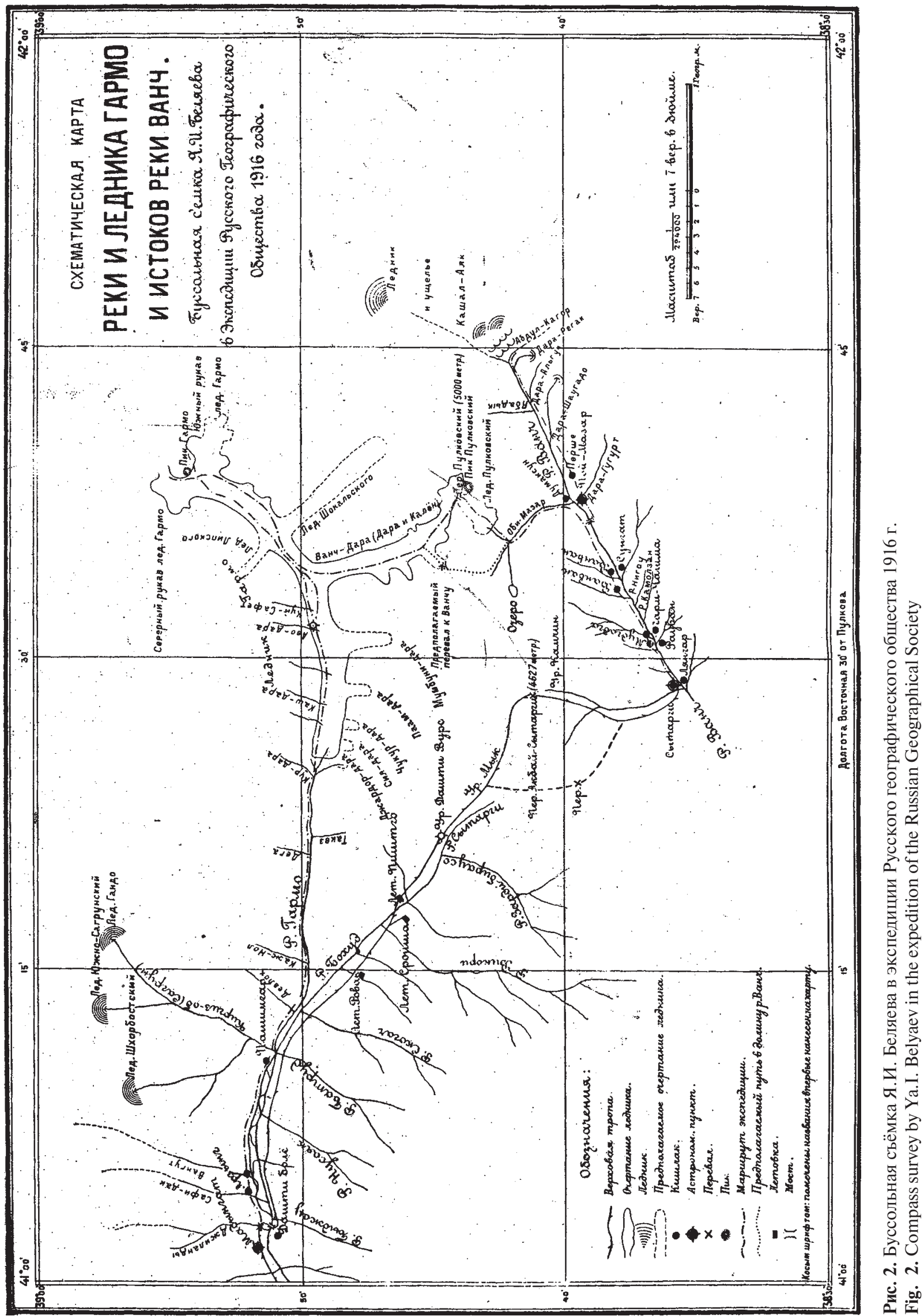




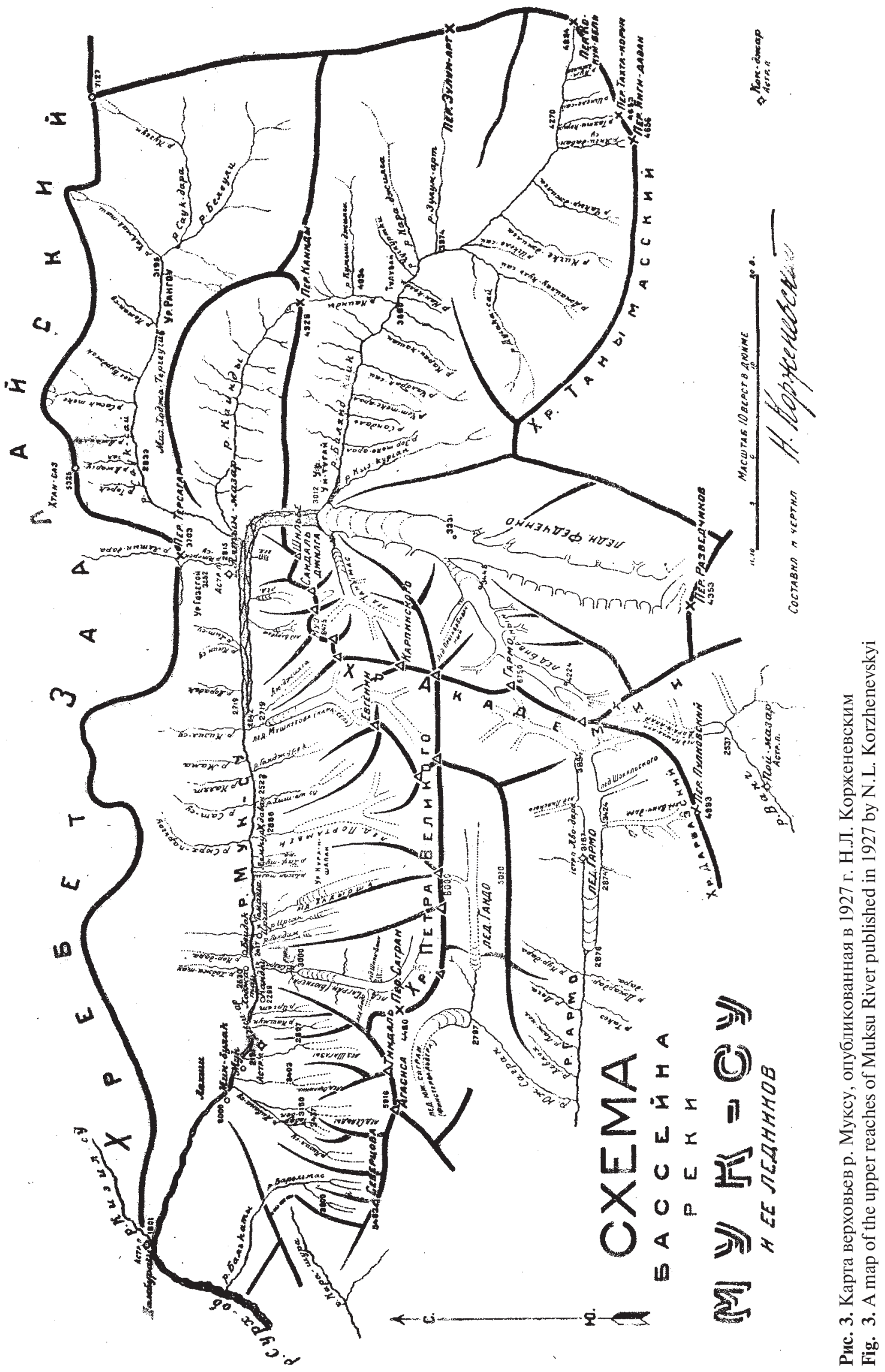



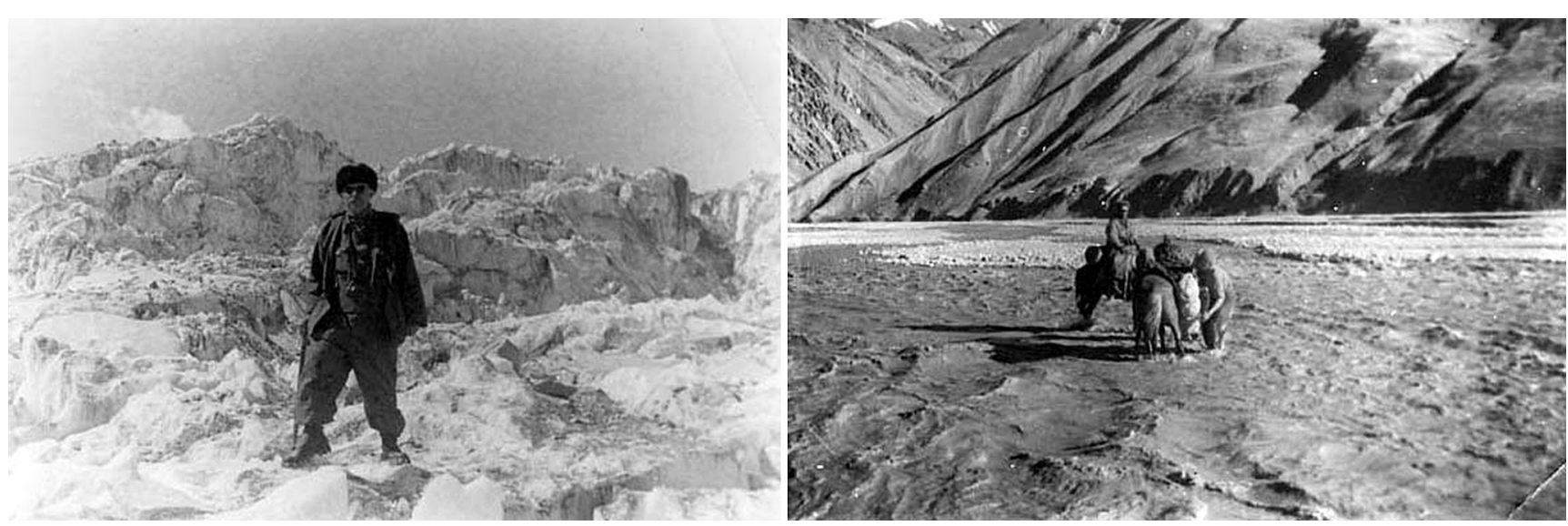

Рис. 4. И.Г. Дорофеев на Памире. Фото слева с подписью на обороте: «Памир, ледник Федченко, хаотическое нагромождение льда». Фото справа с подписью на обороте: «Памир. Трудны, а порой очень опасны переправы через реки Памира». Обе фотографии из архива В.И. Белоусова

Fig. 4. I.G. Dorofeev in the Pamirs. Both photos from the V.I. Belousov's archive

Из письма И.Г. Дорофеева: «Пика с отметкой 7495 метров (который мы называли до 1932 г. пиком Гармо) никто до 1928 г. не видел. Таджики верхних кишлаков долины р. Обихингоу называют пиком Гармо вершину, отстояшую от пика с отметкой 7495 в 18 км южнее. На схеме Я.И. Беляева показана совсем другая вершина. Беляев и не подозревал о существовании вершины с отметкой 7495 м. Он не мог ее видеть с ледника Гармо, она не видна с ледника, пока не обойдешь выступ отрога, отходящего от вершины, которую Беляев назвал Гармо. Можно увидеть ее с хребта Дарвазского, на котором был Яков Иванович, но, видимо, он ее не видел, так как, если бы он ее видел, то исправил бы ошибочно нанесенную вершину, названную им Гармо, если он ее принял за вершину с отметкой 7495, но этого не произошло. Значит, он ее не видел.

Не видели ее и местные жители. Когда я спрашивал их, показывая на нее, они пожимали плечами и говорили, что не знают ее. А когда я спрашивал, знают ли они пик Гармо, - отвечали, что знают и показывали мне его. Это было в 1931 году. Таким образом, нам было известно, что пик с отметкой 7495 метров новая вершина, открытая нами в 1928 году».

На основе ряда исследований начала XX в. Н.Л. Корженевский в 1927 г. опубликовал свою схему расположения хребтов в истоках р. Муксу (рис. 3). На проходящем по оси района меридиональном хребте, который он назвал хребтом Академии Наук, Корженевский нанёс пик Гармо высотой 6750 м как самую высокую вершину района и показал несколько других, пока ещё гипотетических вершин. Схема Корженевского легла в ос- нову работ Таджикско-Памирской экспедиции 1928-1932 гг., которой предстояло окончательно прояснить орографию Памира.

В 1928 г. экспедиция сделала попытку сразу разгадать «загадку узла Гармо». Этим снова занялся И.Я. Беляев. Вместе с альпинистами и несколькими таджиками он поднялся на один из перевалов со стороны р. Танымас, предполагая пройти в истоки Ванча или Язгулема. Но за перевалом оказалось фирновое поле громадного ледника, текущего на север. Отряд ступил на неизвестный ледник, и, идя по нему, Беляев строил различные предположения, постепенно отбрасывая их по разным причинам. Наконец «осталось одно предположение ледник питает р. Муксу, т.е. является не новым ледником, а ледником Федченко, но тогда ледник Федченко приобретает грандиозные размеры, и эти размеры приводили меня в полное смущение».

Таким образом, длина ледника Федченко, которая, как считали в то время, была около 40 км, вырастала до 60-70 км. Через несколько дней после этого открытия на съёмку вышел геодезист И.Г. Дорофеев (рис. 4), который положил на карту весь бассейн ледника Федченко, занявшего почти всё пространство находившегося здесь тогда «белого пятна». Вдоль бортов ледника высилось множество вершин. Одна из них - неправильная усечённая пирамида - особенно заинтересовала Дорофеева. Сравнив свои наблюдения со схемой Корженевского, он решил, что это пик Гармо. Год спустя были обработаны результаты фототеодолитной съёмки Дорофеева и немецких геодезистов, работавших в экспедиции. Высота пирамиды, принятой за пик Гармо, была равна 7495 метров! 


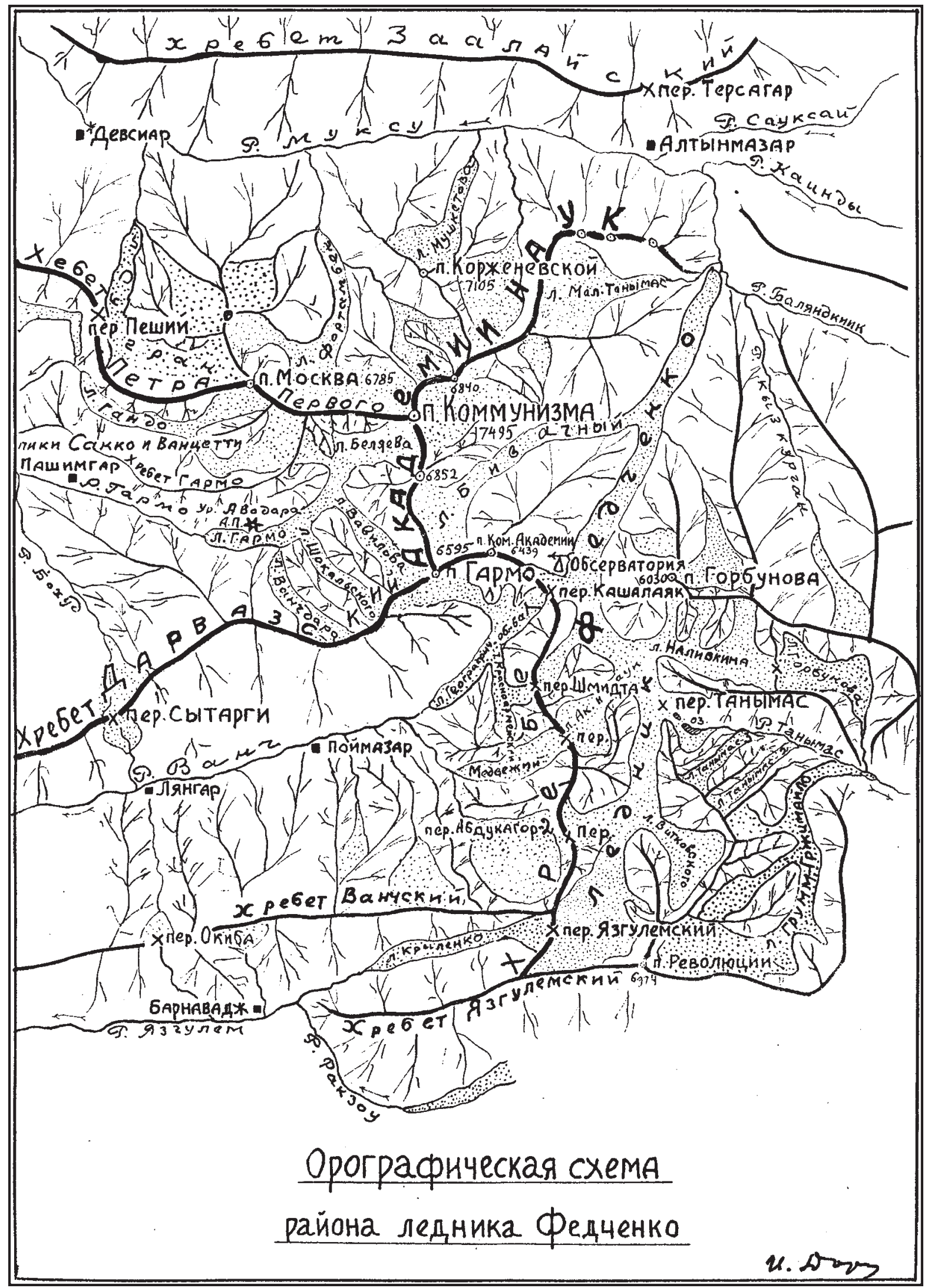

Рис. 5. Орографическая схема района ледника Федченко, составленная И.Г. Дорофеевым

Fig. 5. Orography scheme of the Fedchenko Glacier region compiled by I.G. Dorofeev 


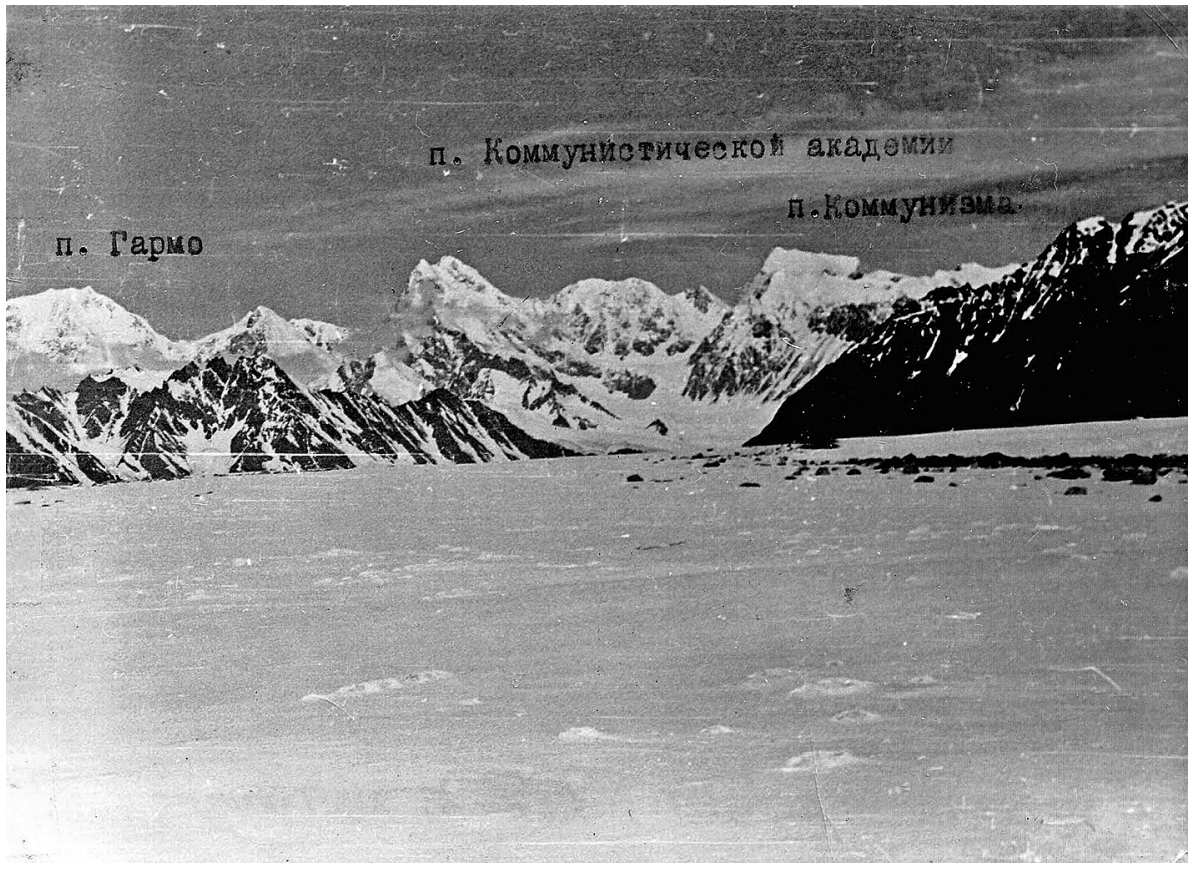

Рис. 6. Фотография И.Г. Дорофеева, сделанная в 1928 г. от перевала Танымас, на которой запечатлены три высочайших памирских пика: Коммунизма, Гармо и Беляева (тогда он назывался пик Коммунистической академии)

Fig. 6. Photo by I.G. Dorofeev made in 1928 from the Tanymas pass, where you can see three highest peaks of the Pamirs: Kommunizma, Garmo and Belyaeva
Начались поиски подходов к этой высочайшей вершине Советского Союза. В 1931 г. три альпиниста во главе с Н.В. Крыленко поднимаются по леднику Гандо, соседнему с Гармо, в надежде увидеть оттуда «Пик Гармо». С седловины хребта, находящейся на высоте 5125 м, альпинисты увидели все окружающие хребты, но самый высокий пик... исчез. Ещё дважды они поднимались на более высокую седловину и одну из ближайших вершин, но могучий пик так и не увидели.

Альпинисты решили провести разведку из долины Гармо. Пробираясь по тропе среди густых зарослей, они постоянно видели впереди впечатляющую вершину - несомненно пик Гармо. Он был виден и с языка ледника Гармо, но затем затерялся среди более близких хребтов и пиков. Решили подниматься по леднику Вавилова и когда уже подошли к подножию массива, непогода заставила повернуть назад. Второй раз попытались увидеть пик Гармо из верховьев ледника Шокальского, но направление хребтов в районе пика, да и непосредственное его окружение заставили усомниться: действительно ли это Гармо? Уже на обратном пути снизу из долины Крыленко взглянул назад и снова увидел пик Гармо и какую-то высокую однозубую вершину, лежавшую вдалеке, чуть севернее.

Из письма И.Г. Дорофеева: «В конце экспедиции 1931 года мы встретились с Н.В. Крыленко на леднике Гармо. Когда Николай Васильевич сказал мне, что он с Бархашем ходил к пику Гармо, расположенному на хребте Дарвазском, я очень удивился, ведь пик, к которому он искал подступы, расположен в стыке хребтов Петра Первого и Академии Наук. Я сказал, что они совершили грубейшую ошибку. Мое заявление было встречено с нескрываемым раздражением. Мы долго спорили, но я так и не мог убедить разведчиков, что они ошиблись. Я напомнил им, что они сами же видели с хребта Заалайского, что пик Гармо с отметкой 7495 метров находится в стыке хребтов Петра Первого и Академии Наук. Они не захотели признать свою ошибку и продолжали стоять на своем. Странная забывчивость. Я подумал, что самолюбие не позволяет им признаться в своей ошибке.

Наконец, я сказал, что таджики называют Гармо другую вершину, а вершину с отметкой 7495 метров они никогда не видели. Следовательно, вершина эта новая, открытая в 1928 году. Крыленко бросил:

- Это презумпция! Ее еще надо доказать! У нас уже нет времени заняться этим вопросом. Отложим до будущего года.»

В 1932 г. было решено напрячь все силы, чтобы разгадать эту запутанную историю. Сразу три отряда альпинистов Таджикско-Памирской экспедиции должны были подниматься к центру «узла Гармо»: с запада (из долины Гармо), с севера (из долины Муксу) и с востока (с ледника Федченко). Отряд Н.В. Крыленко снова шёл из долины Гармо. Ему казалось, что проще будет подняться к пику Гармо по его северному плечу, которое уже не раз видели. Долго пробираются альпинисты по разорванному 

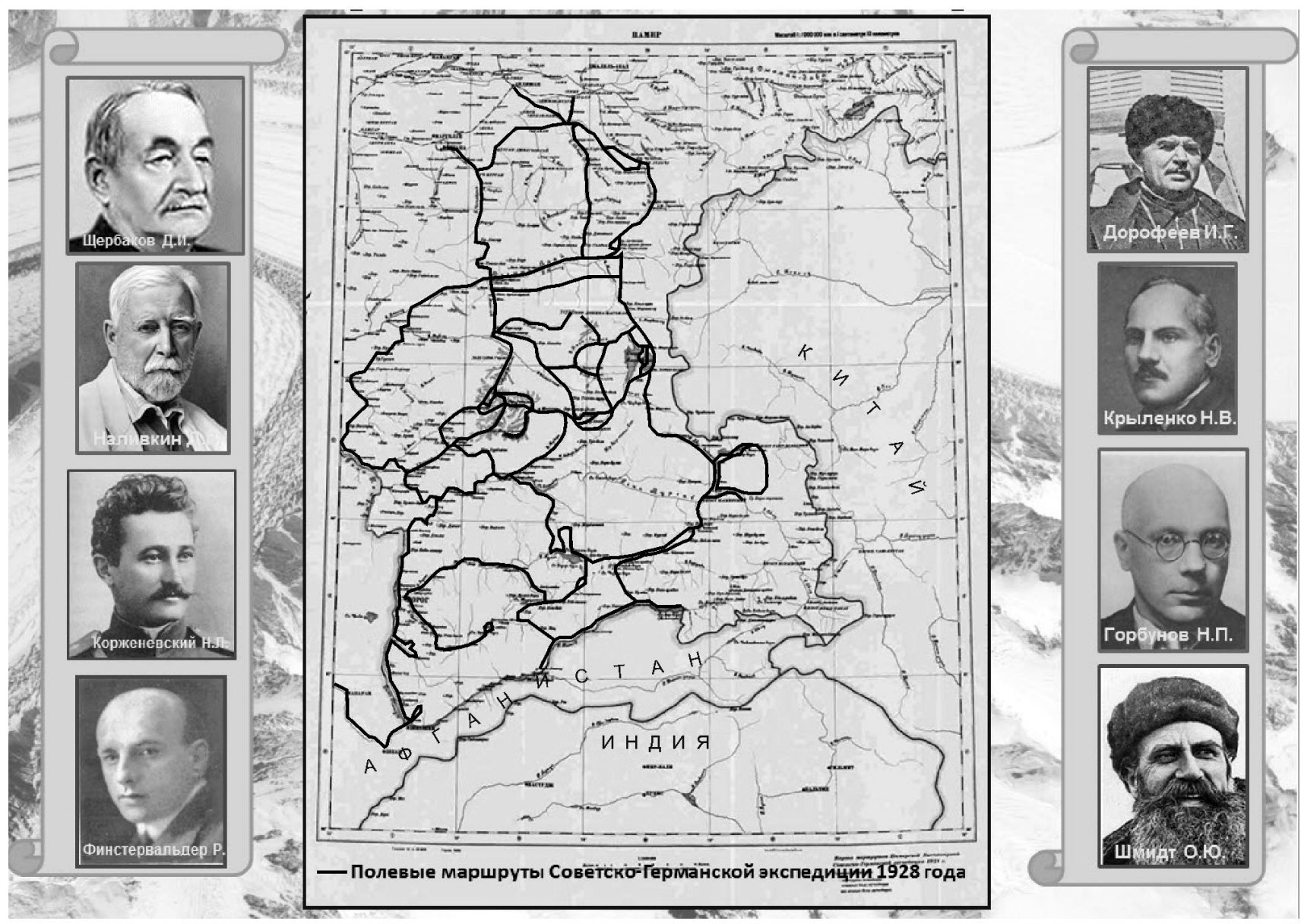

Рис. 7. Первоисследователи Памира и маршруты советско-германской памирской экспедиции 1928 г. Коллаж составлен В.Г. Коноваловым

Fig. 7. Early investigators of the Pamirs and routs of the Soviet-German Pamirian expedition of 1928. Compiled by V.G. Konovalov

трещинами леднику, обходят ледопады и отвесные стены. С одного из скалистых выступов они вдруг видят уходящие вверх оледенелые склоны громадной вершины. «Это был знаменитый, искомый нами пик Гармо... Мы не сомневались в тот момент ни одной секунды, что стоим у самого знаменитого пика, высоту которого в 1928 году определили в 7495 метров, как высочайшую вершину СССР».

Вершина была вся как на ладони и выглядела точно так же, как снизу, из долины Гармо. Надо было рассмотреть её восточные склоны. Для этого решили взобраться на гребень ближайшего хребта. Через несколько часов гребень был «покорён», и к востоку от него люди увидели притоки ледника Федченко, что как будто соответствовало ожидаемой картине. Но... альтиметр показывал высоту 5700 м, тогда как, судя по немецкой карте, этот гребень поднимается на 6700 м.

В это время отряд Н.П. Горбунова разведывал пути к Гармо с востока. Путь с ледника Бивачно- го привёл группу к южному гребню пика, который точно соответствовал тому, что видели раньше. Это и понятно, потому что измеряли и фотографировали вершину «7495» раньше именно с востока. На высоте 6200 м подъём пришлось прекратить из-за непогоды.

Третий отряд под руководством А.В. Москвина двигался к вершине по долине Муксу. Путь оказался длинным и сложным и завершился в ущелье Фортамбек, откуда была видна какая-то очень высокая вершина. Измерили её высоту - получилось 7666 м, т.е. ещё выше, чем «пик Гармо». Вновь возникли сомнения, но они разрешились быстро, так как новая вершина легла точно на место «пика Гармо». Просто последнее измерение её высоты было ошибочным.

Таким образом, летние работы 1932 г. не решили главную проблему.

А вот что пишет в своём письме И.Г. Дорофеев: «В 1932 году я приехал на ледник Гармо за 735 километров с Восточного Памира, чтобы установить надежно, действительно ли вершина с отметкой 


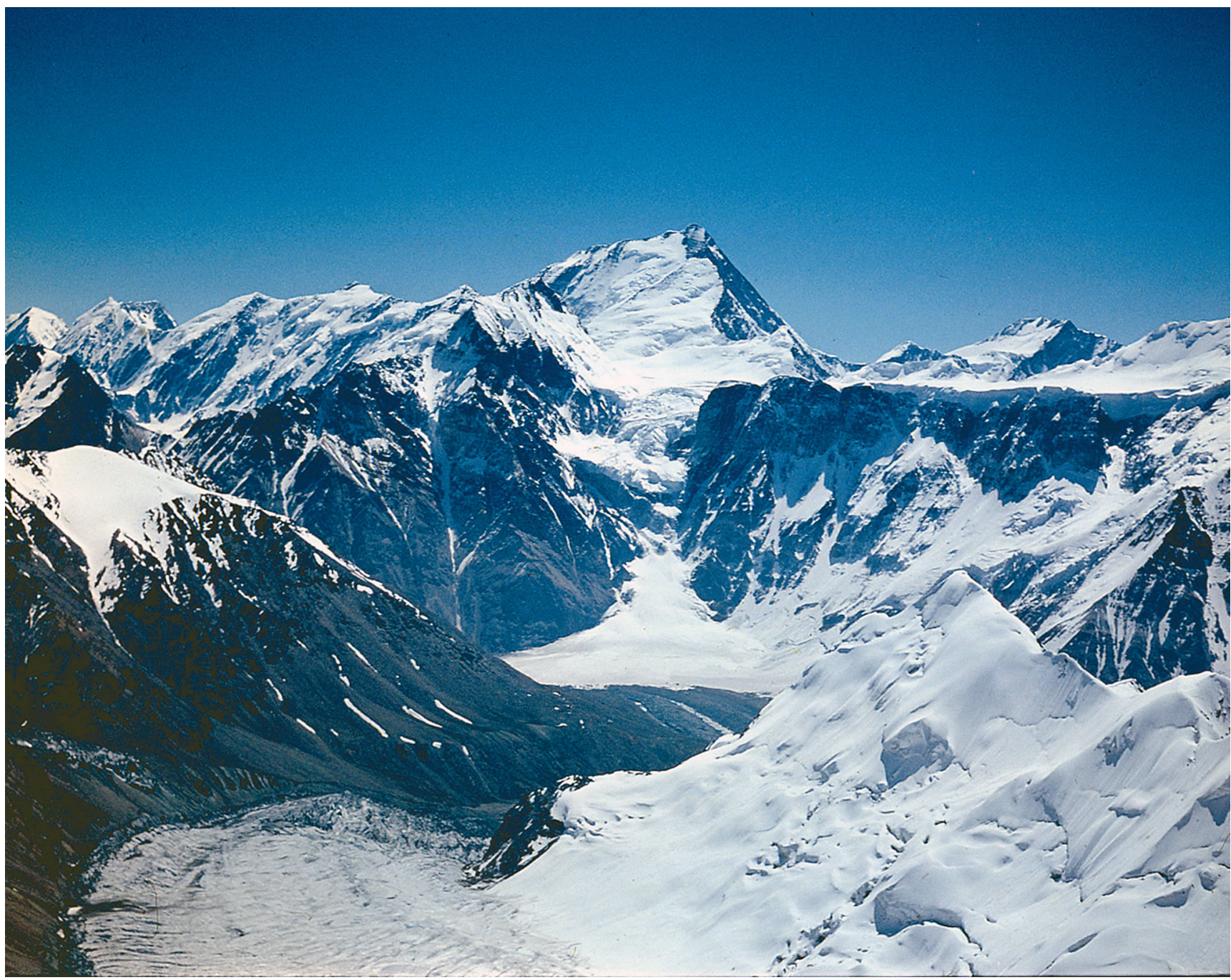

Рис. 8. Пик Исмоила Сомони с севера. Справа - Памирское фирновое плато. Фото О.В. Рототаевой

Fig. 8. Peak of Ismoil Somoni from the north. To the right - Pamirian Firn Plateau. Photo by O.V. Rototaeva

7495 метров - новая вершина, открытая в 1928 году. Приехал и Крыленко. Он с Бархашем упорно продолжали, вопреки здравому смыслу, искать подступы к пику с отметкой 7495 метров не там, где находится он, а там, куда их повели таджики, куда они их водили и в прошлом году, - к своему пику Гармо.

На этот раз мы пошли вместе с Дмитрием Ивановичем Щербаковым. Я нанял в кишлаке Пашимгар других таджиков, чтобы сопоставить их показания с показаниями прошлогодних моих рабочих. И опять было установлено, что пик с отметкой 7495 метров они, местные жители кишлаков в долине Хингоу, не знают. Надо сказать, что этот пик и не видно ни с долины Хингоу, ни с ледника Гармо.

Я посылаю Вам схемы, на которых хорошо видно все то, о чем я говорил (см. рис. 2, 3 и 5). А именно:
1. Чтобы Москвин мог сказать, какой именно пик таджики называют Гармо, ему надо было бы быть минимум в долине Хингоу спросить таджиков, где их пик находится. Но Москвин не был там, с таджиками Пашимгара не встречался, он находился по другую сторону хребта Петра Первого, на леднике Фортамбек.

Я рассматриваю здесь грубейшую неточность, проявленную со стороны Н.В. Крыленко. Но никак не пойму, зачем он сделал это. Не в оправдание ли своей ошибки, которую он не мог признать своевременно из самолюбия?

2. Месторасположение пика с отметкой 7495 метров мне было хорошо известно еще в 1928 году, когда я занимался фототеодолитной съемкой с немецким геодезистом Рихардом Финстервальдером ледника Федченко. Также это было известно и са- 
мому Крыленко в 1931 году, о чем он написал еще в 1931 году в своей книге «Узел Гармо».

Зачем нужно было приписывать это открытие Москвину? Никак не возьму в толк. Вероятно, только для оправдания своих заблуждений в поисках подступов к пику Коммунизма? С легкой руки Крыленко пошла полнейшая путаница в вопросе как открытия пика Коммунизма, так и в определении его месторасположения. Несколько лет назад я послал статью в Президиум ВГО, думая, что ее напечатает журнал «Известия Всесоюзного Географического общества», но мою статью прислали обратно, написав, что она не содержит научного интереса.

3. Меня удивляет еще и то, что Крыленко открытие пика Коммунизма так беспардонно приписывает немцам. На самом деле первым из участников экспедиции Академии наук 1928 года, увидевшим и измерившим направления и вертикальные углы, был я, а не немцы (рис. 6). Мои измерения на пик Коммунизма находятся в журналах полевых топографических работ в экспедиции, в архивах Военно-топографического управления».

Итак, «Пики Гармо», которые видели разные исследователи, в действительности три разные вершины. Одна из них поднимается на севере «распутываемого узла» и достигает 7495 м, эту однозубую вершину не раз видел Н.В. Крыленко из долин Гандо и Гармо. Тогда её назвали пиком Сталина, а позже - пиком Коммунизма. Другая расположена в 18 км к югу - она-то и есть настоящий пик Гармо высотой 6595 м, известный всем таджикам. И наконец, в промежутке между ними лежит пик Беляева высотой 6852 м, который некогда Я.И. Беляев, а вслед за ним Н.Л. Корженевский приняли за пик Гармо.

Так в начале 1930-х годов была окончательно выяснена орография Центрального Памира. В этом выдающемся исследовании, сопровождавшемся целым рядом географических открытий, участвовала великолепная плеяда известных учёных и путешественников первой трети XX в. (рис. 7). И ешё раз подчеркнём огромную роль в этих открытиях Таджикско-Памирской экспедиции 1928-1932 гг.

Нам с вертолёта потребовался всего один час, чтобы увидеть всё то, что люди с такими трудностями открывали в течение нескольких десятилетий, и пролететь совсем недалеко от склонов высочайшей вершины Памира, ныне носящей название пика Исмоила Сомони (рис. 8).

\section{Summary}

The paper tells a story how the «blank spot» at the Pamirs center was puzzled out. In 1878, a small party of explorers headed by V.D. Oshanin had found here a big glacier about $30-40 \mathrm{~km}$ long and named it for Fedchenko. In 1884-85, known investigator G.E. GrummGrzhimailo made his important proposal about orographic structure of the Pamirs central part. In 1890, expedition headed by topographer N.I. Kosinenko investigated the lower part of the Fedchenko Glacier and, for the first time, saw a separate high peak. In 1916, astronomer Ya.I. Belyaev had put on a map a great pyramidal summit but he had mistaken it for the Garmo Peak well known to local Tadzhiks (Fig. 2).

In 1927, N.L. Korzhenevsky published a chart of arrangement of ridges near sources of the river Muksu (Fig. 3) that became a basis for work of the TadzhikPamir expedition of 1928-1932. In 1928, Ya.I. Belyaev determined a true length of the Fechenko Glacier that was $70 \mathrm{~km}$, and geodesist I.G. Dorofeev mapped the whole basin of this glacier (Fig. 4) including also a high irregular truncated pyramid of $7495 \mathrm{~m}$ in height (as he believed). But earlier this summit was identified as known the Garmo Peak. And only in 1932, it was established that definitions made by Dorofeev in 1928 were related to this highest peak of the Pamirs and also of the whole Soviet Union. The chart of real Central Pamir orography constructed by I.G. Dorofeev is presented in the paper together with his letter addressed to the author (Fig. 5).

Thus, the «Garmo peaks» which were observed by the above mentioned explorers were actually three different summits. One of them does tower on the north of the «knot being puzzled out» and reaches $7495 \mathrm{~m}$, and namely this «one-tooth» peak was repeatedly seen by N.V. Krylenko from valleys Gando and Garmo. It was named then the Stalin peak, and later - the peak of Communism. Another one is located in $18 \mathrm{~km}$ southward, and this peak is actually the true Garmo Peak $6595 \mathrm{~m}$ high known to local Tadzhik people. And the third summit is located between the two others, it is the Belyaev Peak $6852 \mathrm{~m}$ high that once Ya.I. Belyaev, and next N.L. Korzhenevsky confused as the Garmo Peak.

So, at the beginning of 1930 s, orography of the Central Pamirs had been finally ascertained. A group of distinguished well-known scientists and travelers of the first third of $20^{\text {th }}$ century (Fig. 7) participated in this outstanding investigation that was followed by a number of geographical discoveries. And, the highest peak of the Pamirs does now bear the name Ismoil Somoni (Fig. 8). 